This is a pre-copy edited version of an article accepted for publication in Screen (Volume 56, Number 1, Spring, 2015) following peer-review. The definitive publisher authenticated version is available from:

http://screen.oxfordjournals.org/content/56/1/64.abstract

\title{
Televisual forensics on the edge of chaos: post-genomic complexity in CSI: Crime Scene Investigation
}

\section{SOFIA BULL}

There is long history on both North American and British television of procedurals that focus on the work of police surgeons, medical examiners or forensic scientists rather than that of police officers or detectives. Apart from rare early examples such as Craig Kennedy: Criminologist (Weiss Productions, 1952), this subgenre first grew to form a recognizable cluster of texts in the 1960s. A number of now largely forgotten programmes, such as Diagnosis: Unknown (CBS, 1960), Police Surgeon (ITV, 1960), Silent Evidence (BBC, 1962) and Thorndyke (BBC, 1964), introduced audiences to the concept of forensic science and laid the foundation for more successful shows such as The Expert (BBC, 1968-76) and Quincy M.E. (NBC, 1976-83). These programmes presented the medico-scientific investigator as a hero of the technocratic revolution, offering a modern and progressive alternative to traditional law enforcement at a time when awareness about police misconduct was on the rise. After largely disappearing from the airwaves during the $1980 \mathrm{~s}$, the genre made a comeback in the late 1990s. Britain witnessed a succession of medicalized crime dramas, including McCallum (ITV, 1995-98), Dangerfield (BBC, 1995-99), Bliss (ITV, 1995, 1997), Silent Witness (BBC, 1996-) and Waking the Dead (BBC, 2000-11), while on the other side of the Atlantic the immense success of CSI: Crime Scene Investigation (CBS, 2000- ) triggered a wave of shows featuring different types of forensic experts, such as Crossing Jordan (NBC, 2001-07), Without a Trace (CBS, 2002-09), Cold Case (CBC, 2003-10), NCIS (CBS, 2003-), Bones (Fox, 2005-) and Numb3rs (CBS, 2005-10), as well as the two spin-offs CSI: Miami (CBS, 2002-12) and CSI: NY (CBS, 2004-13). The forensic crime drama became one of the pivotal television genres of the 2000s and ignited an intense cultural interest in forensic methods. ${ }^{1}$ This most recent forensic turn can also be understood as instilling a sense of trust and security at a time of cultural upheaval; there has been much discussion of its effect in disavowing the anxieties of postmodern and post-9/11 culture with corporeal spectacle and a promise of certainty provided by scientific fact. ${ }^{2}$

Most forensic crime dramas, whether produced in the 1960s or the 2000s, tend to be invested in a fairly conservative discourse on science that ignores and conceals the doubts, uncertainties and shifts that are an inherent part of scientific practice. However, if studied in detail and over time, it is possible to note subtle changes in the way forensic science is figured. Examining the first ten seasons of CSI: Crime Scene Investigation (hereafter $C S I$ ) and comparing it with earlier forensic crime dramas, I argue that in engaging with emergent scientific discourses this programme unsettles some of the simple truths we have come to expect from popular representations of forensic science. CSI's engagement with new developments in molecular science and genetics pose new and timely questions about scientific knowledge and the kinds of information harboured by minuscule biological entities. I argue that CSI at least occasionally acknowledges that an increasingly perceptive scientific gaze could actually result in an augmented sense of complexity and confusion rather than a straightforward rise in scientific knowledge.

This essay is part of a growing body of work examining how popular ideas about biomedicine, molecular science and genetics figure in the media. With reference to José van Dijck's and Lisa Cartwright's studies of scientific imaging technologies, I analyze CSI's digitally produced microscopic imagery as following a long generic tradition of dramatizing a medical gaze able to locate information invisible to the human eye. ${ }^{3}$ The programme specifically stages a 'molecular gaze', and its figuration of DNA evidence generally reiterates 
This is a pre-copy edited version of an article accepted for publication in Screen (Volume 56, Number 1, Spring, 2015) following peer-review. The definitive publisher authenticated version is available from:

the essentialist genetic framework that Dorothy Nelkin and Susan M. Lindee have previously discussed as a prominent feature of popular culture in the 1980s and 1990s. ${ }^{4}$ However, building on the work of Sarah Franklin, Jackie Stacey and others, I discuss certain aspects of CSI's imagery, plotlines and narrative structure as engaging with a new cultural shift whereby genetic reductionism is slowly exchanged with a post-genomic systems biology that since the mid 1990s has emphasized more complex interactions on the level of genes and molecules. ${ }^{5}$ It is primarily narratives about cloning, genetic engineering and biomedical interventions that have thus far been analyzed as expressing such an emergent sense of increased fluidity and unpredictability. With this reading of CSI, I show that post-genomic ideas have begun to circulate more widely, even surfacing in media texts that are still invested in more traditional scientific frameworks and that are not explicitly participating in bioethical debates about radical gene manipulation.

This essay answers a decided need to examine the cultural and aesthetic specificity of television as a stage for contesting ideas about molecular science and genetics. Drawing on John Caldwell's writings about the sensibility of 'televisuality', I argue that CSI's reconfiguration of molecular imagery on a basic level is motivated by the need to attract viewers and distinguish itself stylistically within an increasingly competitive and overcrowded television landscape. ${ }^{6}$ Furthermore, with reference to Jason Mittell's work on narrative complexity in contemporary television and James MacDowell's critique of assumptions commonly made about the meaning produced by narrative closure, I show that CSI's episodic narrative form is crucial for conveying a sense of unpredictability, uncertainty and non-linearity. The programme's articulation of post-genomic ideas is thus rooted in distinctly televisual aesthetic and narrative forms. By extension, I propose that the inherent complexity of television makes it a particularly suitable medium for articulating the dynamic, uncertain and chaotic nature of the post-genomic sensibility.

The majority of CSI's screen time is devoted to the scientific labour of a team of criminalists in Las Vegas working the graveyard shift: a set of tasks mainly focused on visual observation of physical evidence (figure 1). ${ }^{7}$ This follows a long genre tradition of portraying the gaze of the medico-scientific investigator as a particularly important source of new knowledge. Forensic crime dramas are usually riddled with simple yet suggestive shot/reverse-shot sequences that link closeups of evidence with lingering shots of criminalists studying the objects with deep concentration. This shot combination rehearses the long-running western tradition of associating the sense of sight with the power to understand and ultimately control the surrounding world. By conflating the gaze of the television camera with the gaze of a scientist, the Foucauldian notion of the penetrative medical gaze is effectively dramatized: the criminalists are bestowed with the power of knowledge and the subject under investigation is reduced to a controllable object of information. ${ }^{8}$

This shot combination is enacted so frequently and forcefully in CSI that its connotations linger in scenes not literally uniting the two by means of point-of-view shots or eyeline matches; even fantastic shots where the camera moves into the dead body are understood as illustrating the criminalist's penetrative gaze. ${ }^{9}$ Many shots exhibiting evidence that in reality remains invisible are indirectly anchored in the criminalist's perception by mimicking scientific imagery produced by technology that extends human sight. This refers to the fact that scientific imaging technologies have long featured as powerful weapons in the fictional forensic investigator's arsenal. This trope extends back to the infancy of crime literature: the scientifically inclined detectives in stories by Edgar Allen Poe, Charles Dickens and Arthur Conan Doyle were already wielding magnifying glasses, cameras and microscopes. ${ }^{10}$ On television, the criminalists use everything from low-tech flashlights and 
This is a pre-copy edited version of an article accepted for publication in Screen (Volume 56, Number 1, Spring, 2015) following peer-review. The definitive publisher authenticated version is available from:

magnifying glasses to state-of-the-art microscopes and X-rays, which generally reproduce what van Dijck has called 'the ideal of transparency' embodied by scientific imaging technologies. These technologies, and the images they produce, are understood as extending scientific knowledge by granting the medical gaze access to previously hidden spaces. ${ }^{11}$ Footage of a criminalist looking into a microscope was, for example, early on established as a genre marker signifying the criminalist's ability to analyze evidence that remains hidden to other law enforcement personnel. Almost all forensic crime dramas, including Craig Kennedy: Criminologist, Silent Evidence, Thorndyke, The Expert, Quincy M.E. and CSI use the generic image of the scientist by a microscope both diegetically and in promotional material to distinguish its heroes from those in other crime dramas (figures 2 and 3 ).

However, CSI gives scientific imaging technologies far more narrative and visual importance than any of its predecessors. Whereas earlier forensic crime dramas only featured diegetically motivated scientific images when the investigators used technological equipment, CSI incorporates scientific iconography into its overall style; the televisual apparatus itself habitually emulates scientific imaging technologies in spectacular and imaginary ways. Visuals drawing on microscopic imagery, X-ray footage, endoscopic films, MRI, PET and CT scans, and a wide range of digital imagery play a central role in CSI's visual style, which is often described as glossy, excessive and fantastic. ${ }^{12}$ Martha Gever has convincingly argued that the programme's signature look adheres to the sensibility that John T. Caldwell has called 'televisuality'. ${ }^{13}$ CSI's general use of fast-paced editing, montage sequences, dynamic camera movements, expressionistic lighting, colour-saturated imagery and digital special effects follows a wider tendency in contemporary television to 'flaunt and display style ${ }^{, 14}$ as a response to the increased competition that network shows have faced from cable and other distribution channels since the 1980s. While acknowledging that Caldwell somewhat overstates the newness of this logic - visual spectacle has long been used to attract television viewers - I would add that the use of scientifically inspired iconography is another significant way in which CSI attracts audiences through gratuitous visual displays. ${ }^{15}$ As Caldwell's theory suggests, televisuality is a drive that does not simply create an easily distinguishable style, but rather aims to retain the audience's attention by constantly '[reinventing] the stylistic wheel'. ${ }^{16}$ In CSI's case, it is the development of a 'scientific' televisuality that provides the most radically innovative form of attraction, not the general 'cinematic' qualities of the series' visual language. ${ }^{17}$

Microscopic imagery becomes a particularly important reference point for CSI's brand of televisuality, partly because extreme closeups of tiny objects make apt use of the newly digitized television apparatus. That visual magnification was a conscious and central strategy to make CSI appear innovative has been acknowledged by executive producer Carol Mendelsohn, who in an interview celebrating the programme's one hundredth episode stated: 'One of the things we did from the start that was unique was that we didn't go big, we went small. We took a fibre and made it look like a redwood forest. ${ }^{18}$ Hence, rather than looking to cinema for groundbreaking imagery, CSI has revamped the television medium's characteristic penchant for the closeup, augmenting it with the extreme qualities of microscopic imagery and the innovative visuals of digital technology. The most familiar example of this wider tendency is the snap zoom effect that has become widely known as the 'CSI shot'. In previous academic writing, the CSI shot is usually described as specifically depicting the interior of the dead body, but this endoscopic variety is only one of a wide range of snap zoom effects rendering small and hidden objects visible. ${ }^{19}$ For example, in 'Pilot' (series 1, episode 1), the very first example of this special effect mimics the trajectory of a bullet entering a chest wound, but the following two snap zooms magnify a hair follicle and a broken-off nail respectively. Throughout the first ten seasons of CSI there are innumerable snap zooms that 
This is a pre-copy edited version of an article accepted for publication in Screen (Volume 56, Number 1, Spring, 2015) following peer-review. The definitive publisher authenticated version is available from:

approach and enlarge a wide range of organic and inorganic objects, making microscopic iconography a governing logic of the programme's spectacular style.

CSI's scientific televisuality calls for an amendment of Caldwell's assertion that such excessive cutting-edge special effects and aesthetically novel imagery 'resist analysis as content' because they simply exist as spectacles intended to attract audiences on their own terms. ${ }^{20}$ No matter what the initial incentive was for this stylistic reinvention, it spearheads a more extensive genre reconfiguration that ultimately has a substantial impact on the programme's discourse on scientific knowledge. ${ }^{21}$ If CSI's tendency to display spectacular magnifications is considered in relation to the use of extreme closeup and microscopic imagery in earlier forensic crime dramas, it becomes clear that the programme stages the latest step in a longer process whereby the size of physical evidence has gradually become smaller.

Even the earliest programmes regularly featured extreme closeup (sometimes motivated by the diegetic use of a magnifying glass) to depict small pieces of evidence still detectable by the human eye, such as fragments of fabric, grains of sand or wads of hair. ${ }^{22}$ From the mid 1960s forensic crime dramas started occasionally to insert microscopic imagery, diegetically anchored in light microscopes, thus allowing the television audience more detailed scrutiny of objects at this scale (strands, grains or hairs). Subsequently Quincy $M . E$. included a few diegetic images of bacteria or viruses, which probably originated from an electron microscope. ${ }^{23}$ This jump in scale was then more firmly established in the 1990s when programmes like Silent Witness repeatedly featured diegetic microscopic imagery of evidence completely undetectable to the human eye, such as eggs, sperm, cells and bacteria. CSI goes further by imaging strings of DNA, viruses, molecules and even atoms (figure 4).

Furthermore, while all earlier forensic crime dramas adhered to the aesthetic conventions of imagery actually produced by light microscopes, CSI's particular brand of televisuality generally frees the televisual apparatus from the constraint of 'real life' scientific imaging technologies. This often results in a curious reduction in size differential: the imaginary processes of magnification make most objects appear similarly minuscule, no matter if they are actually detectable by the human eye, a magnifying glass, a light microscope or an electron microscope. Tellingly, the seventh season's narrative arc, following the investigation into the 'miniature killer', selfconsciously stages this general visual tendency within the diegetic world. When dealing with a serial killer who has a habit of leaving behind perfect miniatures of each crime scene, the criminalists are forced to relocate their investigation to these microscopic worlds (figure 5). This process alters their understanding of the original crime scenes, which mirrors the way in which the televisual process of magnification alters the perceived materiality of a wide range of objects, conversely pushing them all towards the lower end of the scale.

As a result, a wide range of physical evidence is enveloped within the same explanatory framework, namely that of molecular biology. This extension of the evidence scale engages with a wider cultural shift towards a molecularization and geneticization of science and medicine. ${ }^{24}$ Since the discovery of the double helix in the middle of the twentieth century, knowledge about 'life itself' is increasingly imagined as hiding at the level of molecules and genes, waiting to be decoded by new scientific practices and technologies. The reconfiguration of the forensic crime genre mirrors this wider discursive shift from 'molar' biology to 'molecular' genetics. While earlier forensic crime dramas primarily articulate a traditional biological framework of knowledge by staging a medical gaze that imagines the body as a systematic whole and finds answers on the molar level of organs and tissues, CSI 
This is a pre-copy edited version of an article accepted for publication in Screen (Volume 56, Number 1, Spring, 2015) following peer-review. The definitive publisher authenticated version is available from:

also embraces the more recent genetic imaginary by promoting a molecular gaze that visualizes significant information as hidden at a completely different level. ${ }^{25}$

CSI's scientific televisuality also works in tandem with its wider dramatization of DNA evidence to identify the molecular level as a location for scientific knowledge that is particularly reliable and useful. Based on a quantitative analysis of fifty-one randomly picked episodes from the first six seasons of CSI, Barbara Ley, Nathalie Jankowski and Paul R. Brewer have concluded that thirty-nine per cent of the episodes feature cases where DNA evidence is used to help solve the crime. ${ }^{26}$ DNA evidence often figures as a kind of deus ex machina: it is the ultimate proof that forces the perpetrator to confess and swiftly removes any sense of confusion and doubt at the end of an episode. This narrative reliance on DNA evidence is not completely new. Crime dramas of the 1990s such as Diagnosis Murder, McCallum and Silent Witness already contributed to the 'genetic imaginary' by introducing DNA as a long-living super-molecule providing a reliable basis for locating and identifying individuals over time and space. The crime genre was one of many arenas where 'gene talk' entered the vernacular in the 1990s. As Nelkin and Lindee have shown, a variety of popular texts worked in tandem with a number of highly publicized scientific ventures (such as the Human Genome Project) to render the gene into one of the most powerful cultural icons of this period. ${ }^{27}$ By staging the molecular gaze and narratively constructing DNA evidence as a reliable source of information about both past events and individual identity, CSI reiterates and reinforces many of the deterministic and essentialist ideas about genetics that became a dominant cultural discourse in the $1990 \mathrm{~s} .{ }^{28}$ The process of molecularization could be understood as a mere continuation of the traditional ideal of transparency: by accessing the molecular world the criminalists have extended the medical gaze even further, and forensic science is imbued with a reassuring promise of increased 'certainty, order, predictability and control'. ${ }^{29}$

The study made by Ley, Jankowski and Brewer, however, includes a brief qualitative analysis of how some CSI episodes openly debate the continued viability of genetic essentialism, which suggests that the programme 'both echo[es] and question[s] broader cultural discourses about genetics' ${ }^{30}$ Continuing this line of inquiry, I propose that CSI's televisual reconfiguration of microscopic imagery also contributes to a more multifaceted discourse on molecular science and genetics by dramatizing the molecular world as more complex and uncertain than previously imagined. This is a result of how CSI's more general stylistic traits - namely the dynamic camera movements, expressionistic lighting, colour-saturated imagery and digital special effects - work to emphasize dynamic movement and depth-of-field in its microscopic closeups.

Microscopic imagery featured in earlier forensic crime dramas such as The Expert, Quincy M.E. and Silent Witness always adhered closely to images actually produced by a microscope in a scientific context. Typically displayed with the edges of the screen masked to resemble the round lens of a light microscope, this footage consisted of static images exhibiting a distinct flatness (figure 6). As Cartwright has shown, the reduced depth of field that characterizes microscopic images is actually a consciously constructed aesthetic form, chosen to manage the dynamic qualities of the image, avoid confusion and achieve scientific clarity. ${ }^{31}$ On a basic level, earlier forensic crime dramas reenact this 'aesthetic of flatness' because it has become a marker of scientific 'realism' through its close cultural association with microscopic technology. However, by adopting these stylistic characteristics they also reproduce the 'demand for order, simplicity, particularity and clarity' that governs traditional microscopic imagery., 32

Conversely, CSI's scientific televisuality creates a heightened experience of depth and movement that emphasizes the dynamic qualities of the magnified object. 3D-like 
This is a pre-copy edited version of an article accepted for publication in Screen (Volume 56, Number 1, Spring, 2015) following peer-review. The definitive publisher authenticated version is available from:

footage shows atoms, blood cells or viruses floating around in what looks like a vast space, and the snap zoom effects create an acute sense of the materiality, spatiality and temporality of physical evidence (figure 7). Furthermore, in accordance with the televisual drive to continuously provide the audience with new imagery, CSI keeps reinventing the process of visual magnification. ${ }^{33}$ While the microscopic iconography functions as a recurrent reference, the programme's scientific televisuality does not adhere to one static formula that continuously repeats the same imagery. Instead it stages aesthetic transformations that offer new imaginative visualizations over the episodes and seasons. Hence, rather than attempting to reduce the complexity of the world being depicted, the programme stages ever-changing multisensory roller-coaster rides that enhance the messy nature of the bodies, physical objects and events being scrutinized by the criminalists.

By creating such a heightened sense of complexity, CSI also engages with a wide-ranging number of ideas about dynamic systems, nonlinearity and unpredictability that have increasingly circulated within the fields of molecular science and genetics since the early 2000 s. $^{34}$ These ideas can be characterized as part of an emergent post-genomic discourse because they interconnect with a recent, still embryonic, shift within the genetic imaginary, largely engendered by the outcomes of a number of attempts to decipher the DNA molecule during the 1980s and early 1990s. ${ }^{35}$ The Human Genome Project was initiated with the aim of fulfilling the essentialist genetic promise that science would finally be able to understand and explain life itself once the messages hidden inside the gene were decoded. However, in the wake of this groundbreaking project reaching completion in the early 2000 s, we have been faced with the possibility that such endeavours have brought forth more questions than they have straightforward answers. With this insight, the reductionism of essentialist genetics is increasingly at risk of becoming old fashioned. ${ }^{36}$ Rather than searching for underlying laws and overarching explanations, molecular science is gradually shifting its focus onto dynamic, complex and open systems. ${ }^{37}$ This development actually seems to augment a sense of unpredictability, uncertainty and lack of control, even if the scientific community still tends to discuss its efforts as attempts to increase knowledge. ${ }^{38}$ Because it is continuously reinvented, CSI's televisual scientific imagery exudes a sense of unpredictability that becomes associated with the molecular world. While not yet a dominant part of the programme's discourse on science, this post-genomic sensibility can be identified as an embryonic presence that gradually grows more fully realized as the dynamic microscopic imagery slowly accumulates over the episodes and seasons.

The distinctly televisual nature of CSI's articulation of post-genomic ideas becomes more apparent when compared to the 1990s cloning films that Jackie Stacey has discussed as giving 'cinematic life' to the gene after Dolly the Sheep had intensified our fascination with making genetic processes visualizable. As Stacey's study shows, films like Gattaca (Andrew Niccol, 1997) and Code 46 (Michael Winterbottom, 2003) are characterized by a 'geneticized aesthetic' that emphasizes the mimetic qualities of both cloning and cinema as kindred technologies of imitation: the genetically engineered body is presented 'through a number of familiar cinematic tropes of visual deception: twinning, mirroring, doubling, impersonation, and masquerade'. ${ }^{39}$ This distinctly cinematic 'spatialization' of geneticized biological bodies articulates the increased unpredictability and uncertainly of the emergent post-genomic era, but unlike CSI's scientific televisuality it firmly constitutes this development 'as a threat to authenticity, relatedness, individuality, and uniqueness' ${ }^{40}$ CSI does feature plotlines and other formal elements that similarly express worries about postgenomic scientific practices as undermining the essentialism of traditional genetic discourse, but the series' scientific televisuality substitutes the cinematic focus on repetition and symmetry with a televisual emphasis on change and diversity. That CSI's televisual formation 
This is a pre-copy edited version of an article accepted for publication in Screen (Volume 56, Number 1, Spring, 2015) following peer-review. The definitive publisher authenticated version is available from:

of the molecular world constitutes it as dynamically open, rather than problematically repetitive, is party due to the way in which the programme's spectacular scientific imagery works in tandem with its narrative structure. In the remainder of this essay I move beyond visual spectacle, and instead discuss a number of narrative elements that are equally crucial for the programme's articulation of post-genomic complexity.

The emergent shift in perspective towards a focus on complex systems in molecular science can be understood as part of a wider cultural tendency to express fascination with - and invest value in - ideas about complexity, unpredictability and nonlinearity across a range of different fields and discourses in the late twentieth century. ${ }^{41}$ This trend has, for example, also been visible in the field of television studies where a number of recent studies have identified the television medium as complexly structured, particularly in terms of its storytelling practices. ${ }^{42}$ The most influential instance is Jason Mittell's assertion that a new type of narratively complex television dramas has emerged on American television since the 1990s; such shows characteristically downplay the need for plot closure in individual episodes and instead foreground longer story arcs and self-reflexive 'narrative spectacles' ${ }^{43}$ Mittell's writing on narrative complexity is partly interlinked with a call for a more 'evaluative' approach to television criticism, and his basic definition of complexity results in an implicit devaluation of the classic episodic format, which is largely discarded as comparably reductive. ${ }^{44}$ In view of this, I should point out that I am not defining narrative complexity as a marker of value but rather as a range of formal aspects articulating a set of qualities (openness, unpredictability, nonlinearity, and so on) that are also central to the emergent post-genomic discourse.

Furthermore, the television medium encapsulates far more ways of conveying dynamic uncertainty than the serial narrative structure. In CSI's case, for example, it is certain elements of its episodic form that contribute to a new construction of forensic science as revealing the (molecular) world as an inherently complex place.

In comparison to serial crime dramas like The Wire (HBO, 2002-08), The Killing (AMC, 2011-13) and Top of the Lake (Sundance Channel, 2013) CSI's narrative form is indeed strictly and conventionally episodic: the vast majority of its episodes feature parallel A and B plots focused on discrete criminal cases that are solved by the end of each episode. ${ }^{45}$ While CSI generally utilizes what Robin Nelson has termed a 'flexi-narrative' form (the episodic plots are complemented by more long-running story arcs bridging several episodes or seasons), most of its longer plotlines are easily ignored by all but the most devoted viewers. ${ }^{46}$ Unlike many of the shows discussed by Mittell, CSI has never been associated with 'binge viewing' practices or 'water cooler conversations' but rather with endless reruns. This is a testament to its status as a conventional network television show, with interchangeable episodes that can still be enjoyed when watched in a fragmented and jumbled fashion. However, like most procedurals narrated strictly from the perspective of the investigators, CSI's short episodic arcs possess an inherent complexity because the wider stories about the events surrounding the crime (largely taking place offscreen) are difficult for viewers to infer with any certainty while the investigation is ongoing. In other words, episodic procedural dramas can rarely be described as having a straightforwardly linear plot; they are typically layered narratives that deal with the difficulty of reconstructing a story without having all the facts. It is easy to assume that CSI presents forensic science as a simple solution to this intrinsic problem of how to know the past with any certainty. Most of the earlier forensic crime dramas celebrated forensic science as an exceptionally effective and trustworthy method for ascertaining reliable information about past events through analysis of physical evidence. Physical evidence is given an important narrative role in all forensic crime dramas due to its cultural status as an indexical trace of events, objects or individuals removed in time 
This is a pre-copy edited version of an article accepted for publication in Screen (Volume 56, Number 1, Spring, 2015) following peer-review. The definitive publisher authenticated version is available from:

and space. The discovery of a new piece of evidence not only functions as a catalyst driving the investigation forward, but also allows the viewers to infer more information about the events surrounding the crime.

This generic tradition is both continued and reconfigured by CSI. Partly due to the show's insistence that criminalists now can access and analyze more minuscule pieces of evidence than previously, trace evidence figures even more prominently and frequently in CSI than in programmes like Quincy M.E. or Silent Witness. However, while most earlier forensic crime dramas tended exclusively to include physical evidence of actual narrative importance (that revealed a relevant and crucial piece of information about the crime), CSI's tendency to showcase a veritable smorgasbord of minuscule evidence regularly acknowledges that some traces can throw the investigation off track and result in a far less linear understanding of past events. On CSI most crime scenes contain red herrings and the criminalists have to figure out which pieces of evidence actually contain information relevant to solving the crime. This means that CSI's episodic plotlines can be described as a succession of iterative cycles presenting a number of tentative solutions rather than a straightforward linear development. These are narratives of trial and error: new physical traces are repeatedly recovered, analyzed and interpreted, sometimes with different outcomes. The process might reveal new useful facts, but it could also result in problematic assumptions, faulty hypotheses or irrelevant facts that have to be refuted by new evidence.

The complexity of this iterative episodic structure is enhanced by CSI's repeated use of flashback that further disrupts the generic cause-and-effect logic of the plot, as Gever has noted. ${ }^{47}$ Although earlier forensic crime programmes rarely used flashback, it is still a longstanding narrative device in crime drama, typically used to visualize verbal testimonies. Generically such flashbacks have tended to corroborate the stories told by witnesses, victims or suspects, though they are occasionally used to highlight the subjectivity and partiality of memory. So even though temporal jumps can add to the complexity of a narrative, flashbacks are usually presented as fairly reliable accounts of past events, driving the plot as well as the story forward in a linear fashion. CSI's use of flashbacks, however, is comparatively more unconventional and unreliable, and they can be triggered by verbal testimony or the analysis of physical evidence. Considering the programme's overall construction of witness testimonies as unreliable, it is not surprising that many of the flashbacks motivated by verbal accounts are later revealed to depict either misconceptions or outright lies. However, flashbacks instigated by physical evidence are also habitually exposed as being similarly unreliable. The regular viewer of CSI will quickly learn that all types of flashback have an uncertain truth claim: it is rarely instantly clear if they show 'actual' events, subjective accounts, or theories of what has happened (that could be either right or wrong). Because all flashbacks are presented in a similarly expressionistic style, the viewers are never given any reliable tools for deciphering which are true. Hence these flashbacks not only impact the linearity of the plot about the investigation (which is broken up by periodic time warps), but also result in a story about the crime that is both fragmentary and (at least until the very end) uncertain.

Working in tandem with the programme's scientific televisuality, the iterative structure and unreliable flashbacks stage the world as a more complex place than we had initially assumed. Pieces of physical evidence are not constructed simply as indexical traces, but as nodes in a dynamic web of temporal and spatial relationships. Furthermore, the narrative structure articulates the possibility that an increasingly perceptive scientific gaze might produce too much information. CSI is not the type of crime drama where it is possible to guess the solution. Until the end of each episode, the narrative structure is characterized by 
This is a pre-copy edited version of an article accepted for publication in Screen (Volume 56, Number 1, Spring, 2015) following peer-review. The definitive publisher authenticated version is available from:

a series of unresolved moments that - albeit in passing - express a post-genomic sense of openness, unpredictability and uncertainty.

One of the reasons why the more complex aspects of CSI's episodic structure may have received little previous attention is that the vast majority of the episodes eventually provide some form of narrative closure. The crimes are solved and for guaranteed clarity we are usually offered a clear verbal explanation that lays out the surrounding events in a coherent chain: a narrative device reminiscent of the end-monologues in Agatha Christie's classic crime novels. While the iterative structure and habitual use of flashback momentarily disrupt the traditional cause-effect logic, it is easy to assume that the narrative closure automatically results in a reinstated equilibrium that reduces any previous sense of uncertainty.

However, CSI's tendency to conform to episodic norms of closure and resolution cannot be understood as completely negating its unresolved moments. While the ending is no doubt a significant narrative device often given much cultural importance, we need to remember that endings alone do not tell the whole story, and furthermore that there are many different forms of narrative closure, not all reductive and conservative. ${ }^{48}$ James $^{2}$ MacDowell's critique of a tendency in film studies to overuse the often underdefined concept of 'the happy ending' as a 'bad object' could fruitfully be adapted to the field of television studies, which would benefit from more in-depth studies of what meanings the closed episodic form actually results in. ${ }^{49}$ As MacDowell points out with reference to the Hollywood happy ending, it is often assumed that narrative closure always brings about resolution and by default is a normative and ideologically conservative form. ${ }^{50}$ To set up an artificially simplistic binary between closed and open endings can function as a forceful rhetorical move, useful for celebrating a certain type of programme or taking an ideological stance, but it risks missing significant nuances.

If studied in more detail, it becomes clear that many of CSI's episodic plotlines end with solutions where any sense of closure, certainty and order is at best precarious. While the criminalists are always able to establish what happened, the suspicious deaths under investigation often turn out to be the result of random, unpredictable or complex interlinked events rather than premeditated and logical acts that could have been avoided. For a show about crime scene investigation, death is surprisingly often figured as a random occurrence that can happen to anyone, at any time, and without any warning. For example, in the poignantly titled episode 'Ending Happy' (series 7, episode 21), the iterative attempts at solving a mysterious death finally reveal that a much hated former boxer died from accidentally falling into a pool due to a broken chair, even though there had been multiple serious attempts on his life the very same day. Furthermore, implicit to the solution of 'Ending Happy' is the sense that this early death is the unavoidable result of a number of interlinked circumstances. While the repeated assassination attempts did not directly kill the boxer, a complicated set of events conspired to make him sit down on a broken chair at the end of the day, inadvertently causing his death.

This is only one of numerous plotlines that end in the knowledge that a series of small and seemingly insignificant events can have unexpectedly severe outcomes. For example, in 'Feeling the Heat' (series 4, episode 4) a man accidently electrocutes himself after a homemade swamp-cooler short-circuits his massage chair; in 'Revenge is Best Served Cold' (series 3, episode 1) a gambler dies of lead poisoning from his favourite brand of chocolate, made from West African coca plants that have soaked up acid rain; and in 'Chaos Theory' (series 2, episode 2) a college student is squashed to death behind a trash container due to a series of interlinked events (a love affair, a faulty garbage chute, excessive rain and a traffic jam). The sense of complex interconnectedness and randomness that such solutions 
This is a pre-copy edited version of an article accepted for publication in Screen (Volume 56, Number 1, Spring, 2015) following peer-review. The definitive publisher authenticated version is available from:

produce become even more prominent in episodes such as 'Homebodies' (series 4, episode 3), '4x4' (series 5, episode 19) or 'Happenstance' (series 7, episode 8), in which CSI's usually fairly discrete A and B plotlines turn out to be connected. As Mittell points out, most shows with this type of structure tend to feature A and B plots that simply 'offer thematic parallels or provide counterpoint to one another'. ${ }^{51}$ In $C S I$, however, previously separate plotlines suddenly interweave at the level of action when different investigations unexpectedly collapse into each other. Such instances not only diverge from storytelling conventions in ways that provide pleasure by adding an element of surprise, but also require the viewers to reexamine the cause-and-effect order of previous events in the episode; both effects produce an increased sense of uncertainty and indeterminacy.

Rather than bringing closure, CSI's unexpected solutions and interwoven plots convey a sense of unpredictability that is also acknowledged within the diegesis. In his endmonologue in 'Chaos Theory', the head criminalist Gil Grissom references the so-called 'butterfly effect' when explaining that the solution in this case is 'messy and unlikely' and that life in general is 'unpredictable'. The butterfly effect is a metaphor made popular by mathematician and meteorologist Edward Lorentz, describing the idea that a very small change at one point in a complex system can have large effects elsewhere. ${ }^{52}$ This is only one of many theories about nonlinearity that are increasingly being used to explain technological, social, biological and physiological systems. The concept of nonlinearity brings with it the insight that predictions are impossible even in deterministic systems (even under consistent circumstances a specific 'cause' might result in different 'effects'), which points to an inherent uncertainty in complex systems of both the natural and social worlds. ${ }^{53}$ CSI does not simply reference this wider cultural discourse diegetically, it actively contributes to this shift in perspective by repeatedly featuring solutions that construct death as the outcome of multiple interconnected events that are impossible to foresee and avoid.

The episodic format of CSI therefore does not necessarily result in an increased sense of control and certainty. In addition to exposing the world as an inherently uncontrollable and uncertain place, many of the episodic endings further emphasize this by presenting a solution that makes it hard to identify one clearly innocent victim or guilty perpetrator. As Elke Weissmann's study shows, the majority of the programme's episodes portray the circumstances of crime as decidedly 'messy' in a way that undermines any coherent legal discourse. ${ }^{54}$ This evasion of moral closure is further enhanced by the programme's general ambiguity in tone: CSI regularly features 'quirky' and outright comical plotlines that undermine morality by casting murder or manslaughter as a spectacular curiosity or humorous oddity rather than a serious threat against society. In other words, CSI's episodic structure does not primarily construct forensic science as a tool for placing blame, inflicting punishment, achieving justice or creating a safer world, but rather as a means to study the world in all its strangeness and messiness. Furthermore, this sense of disorder is not so much presented as a failure of law enforcement to ensure order, but rather as an inherent quality of life 'on the edge of chaos' that we are only beginning to understand now that the scientific gaze is becoming more perceptive.

In arguing that CSI figures an inherently dynamic, unpredictable and messy molecular world, I am not proposing that it celebrates or promotes a post-genomic perspective in any straightforward way. While it begins to articulate contemporary ideas about complexity, CSI's overall discourse on science displays strong conservative and reductionist tendencies. When compared with many academic and scientific voices within the current cultural debate about genetics and molecular science, the programme displays far less conviction about the progressive nature of a post-genomic framework of explanation. ${ }^{55}$ Alongside the dynamic use 
This is a pre-copy edited version of an article accepted for publication in Screen (Volume 56, Number 1, Spring, 2015) following peer-review. The definitive publisher authenticated version is available from:

http://screen.oxfordjournals.org/content/56/1/64.abstract

of microscopic imagery and unreliable flashback, CSI's overall visual language and narrative structure still remain invested in the controlling tendencies associated with traditional biological and genetic frameworks. The residual presence of the medical gaze and the programme's adherence to the essentialist genetic imaginary are only gradually being joined by a still-emerging post-genomic sensibility.

Many of the formal aspects that I have analyzed only become noticeable when studied over a period of time, partly because these elements have accumulated and grown more prominent over the fourteen years that CSI has been on air. It could thus be argued that long-running television programmes provide particularly fruitful material for the mapping of emergent cultural discourses. The constant repetition and variation of a television series easily lends itself to a gradual articulation of new cultural ideas that are slowly tested and debated alongside more established perspectives and concepts. Furthermore, it could be argued that the televisual medium has an inherent propensity for dynamic imagery and complex narration that makes it particularly suitable for articulating the post-genomic sensibility. CSI is by no means the only television programme where the televisual drive for spectacular imagery stages a molecularization process, and there are plenty of other examples where narrative complexity produces a sense of unpredictability and openness across a wide range of television genres and formats. More specifically, many of the aspects I have discussed here are also characteristic of a wider number of forensic crime dramas produced during the same period. This is not surprising, as CSI's huge domestic success no doubt functioned as the catalyst for the wave of forensic-centred crime dramas that hit the US television landscape in the 2000 s, as well as for many of those that were subsequently produced in other parts of the world. ${ }^{56}$ Although procedurals that focus more closely on the investigative techniques of pathologists and medical examiners (such as Silent Witness, Crossing Jordan and Bones) have typically favoured special effects that render the dead body spectacular on a traditional molar level, CSI's two highly successful spinoffs, CSI: Miami and CSI: NY, both share the original's fondness for extreme magnification. This is also the case for the genre hybrid House (Fox, 2004-12), which regularly features microscopic 'CSI shots' when portraying a team of medical doctors hunting a different category of lethal perpetrators: viruses, bacteria and genetic diseases. Perhaps even more so than the shows in the CSI franchise, House identifies genetics and molecular science as the medico-scientific frontier that we have only just started to understand and that we might never fully control. While Dr House is portrayed as a medical genius, the programme does not shy away from showing its heroes struggling to access and understand the world of disease.

This sense of uncertainty is also a result of House's use of the same iterative episodic format as CSI. In this case the cyclical structure follows a series of medical tests and treatments, but only the last will actually provide the cure; while some treatments may provide temporary relief, most will have no impact at all and many make the patients even more unwell. The viewers are thus introduced to a world with an abundance of deadly diseases, most caused by minuscule entities that cause disproportionately catastrophic results, and many which attack the body in ways that are hard to predict and often impossible to avoid. Other contemporary programmes engage with such post-genomic ideas about unpredictability and nonlinearity in even more apparent ways, most obviously Fringe (Fox, 2008-13), in which a FBI agent joins with a fringe scientist and his son to investigate unexplained events across alternative timelines and parallel universes.

CSI does, however, stand out amongst the more conventional forensic crime dramas as the show most fascinated with post-genomic science and least willing to make straightforward moral judgements. Both CSI: Miami and CSI: NY devote far more screen time to untangling the morals of each case in ways that help to establish responsibility, blame and 
This is a pre-copy edited version of an article accepted for publication in Screen (Volume 56, Number 1, Spring, 2015) following peer-review. The definitive publisher authenticated version is available from:

http://screen.oxfordjournals.org/content/56/1/64.abstract

guilt. As implied by a voiceover at the end of CSI: Miami's pilot episode 'Golden Parachute' (series 1, episode 1), the spinoffs are more prone to present forensic science as a tool for bringing justice to 'innocent victims who are powerless': the criminalists in CSI: Miami do their outmost to take control and bring order to the chaos. Conversely, CSI at least partially acknowledges that forensic science might be best understood as a tool for mapping and explaining the chaos and uncertainty that is an inherent part of a post-genomic molecular world.

\footnotetext{
${ }^{1}$ See Lindsay Steenberg, Forensic Science in Contemporary American Popular Culture: Gender, Crime and Science (New York, NY: Routledge, 2013)

${ }^{2}$ See, for example: Charlotte Brunsdon, 'Structure of anxiety: recent British television crime fiction', Screen, vol. 39 no. 3 (1998), p. 242; Dennis Broe, 'Genre regression and the new Cold War: the return of the police procedural', Framework, vol. 45 no. 2 (2004), pp. 81-101; Michele Byers and Val Marie Johnson (eds), The CSI Effect: Television, Crime and Governance (Plymouth: Lexington Books, 2009).

3 José van Dijck, The Transparent Body: a Cultural Analysis of Medical Imaging (Seattle, WA: University of Washington Press, 2005); Lisa Cartwright, Screening the Body: Tracing Medicine's Visual Culture (Minneapolis, MN: University of Minnesota Press, 1995).

${ }^{4}$ Dorothy Nelkin and Susan M. Lindee, The DNA Mystique: the Gene as a Cultural Icon (New York, NY: W. H. Freeman, 1995).

${ }^{5}$ Sarah Franklin. 'Global nature and the genetic imaginary', in Sarah Franklin, Celia Lury and Jackie Stacey (eds), Global Nature, Global Culture (London: Sage, 2000); Joan Haran, Jenny Kitzinger, Maureen McNeil and Kate O'Riordan, Human Cloning in the Media: From Science Fiction to Science Practice (Oxford: Routledge, 2008); Anneke Smelik and Nina Lykke (eds), Bits of Life: Feminism at the Intersection of Media, Bioscience and Technology (Seattle, WA: University of Washington Press, 2008); Jackie Stacey, The Cinematic Life of the Gene (Durham, NC: Duke University Press, 2010).

${ }^{6}$ John Thornton Caldwell, Televisuality: Style, Crisis and Authority in American Television (New Brunswick, NJ: Rutgers University Press, 1995).

${ }^{7}$ The term 'criminalist' is synonymous with 'forensic scientist' and describes anyone with some sort of science degree collecting and examining physical evidence of crime. It thus encapsulates both crime scene investigators and laboratory technicians.

${ }^{8}$ Michel Foucault, The Birth of the Clinic: an Archaeology of Medical Perception (1963) (London: Routledge,
} 2008).

${ }^{9}$ See, for example: Martha Gever, 'The spectacle of crime digitized: CSI: Crime Scene Investigation and social anatomy', European Journal of Cultural Studies, vol. 8, no. 4 (2005), p. 457; Sue Tait, 'Autopic vision and the necrophilic imaginary in CSI', International Journal of Cultural Studies, vol. 9, no. 1 (2006), p. 47; Elke

Weissmann and Karen Boyle, 'Evidence of things unseen: the pornographic aesthetic and the search for truth in CSI', in Michael Allen (ed.), Reading CSI: Crime TV Under the Microscope (London: IB Tauris, 2007), p. 97.

${ }^{10}$ See Ronald R. Thomas, Detective Fiction and The Rise of Forensic Science (Cambridge: Cambridge University Press, 1999).

${ }^{11}$ van Dijck, The Transparent Body, pp. 5-7.

${ }^{12}$ See, for example: Karen Lury, Interpreting Television (London: Hodder Arnold, 2005) p. 46; Sue Turnbull, 'The hook and the look: CSI and the aesthetics of the television crime scene', in Allen (ed.), Reading CSI, p. 25; Deborah Jermyn, 'Body matters: realism, spectacle and the corpse in CSI', in Allen (ed.), Reading CSI, p. 81.

${ }^{13}$ Gever, 'The spectacle of crime digitized', pp. 448-49.

${ }^{14}$ Caldwell, Televisuality, p. 5.

${ }^{15}$ See Mimi White, 'The attractions of television: reconsidering liveness', in Nick Couldry and Anna McCarthy (eds), MediaSpace: Place, Scale and Culture in a Media Age (London: Routledge, 2004), pp. 85, 90; Helen Wheatley, 'Beautiful images in spectacular clarity: spectacular television, landscape programming and the question of (tele)visual pleasure', Screen, vol. 52, no. 2 (2011), pp. 238-39.

${ }^{16}$ Caldwell, Televisuality, p. 6.

${ }^{17}$ Ibid., p. 12.

${ }^{18}$ Carol Mendelsohn, quoted in Ray Richmond, 'The minds behind the bodies', Hollywood Reporter Special issue: CSI 100th, 18 November 2004, <http://www.hollywoodreporter.com/> (accessed March 1, 2010).

${ }^{19}$ The scholarly interest in the body-centred CSI shots is not surprising as this type of footage is particularly gruesome and clearly reminiscent of effects seen previously in other popular texts, including the cult-classic science fiction film The Fantastic Voyage (Richard Fleischer, 1966) and blockbusters such as Three Kings 
This is a pre-copy edited version of an article accepted for publication in Screen (Volume 56, Number 1, Spring, 2015) following peer-review. The definitive publisher authenticated version is available from:

http://screen.oxfordjournals.org/content/56/1/64.abstract

(David O. Russell, 1999) and Fight Club (David Fincher, 1999). See, for example: Lury, Interpreting Television, p. 35; Weissmann and Boyle, 'Evidence of things unseen', p. 94; Tait, 'Autopic vision', p. 54.

${ }^{20}$ Caldwell, Televisuality, p. 5.

${ }^{21}$ Caldwell's chapter on the negotiation of race in the television coverage of the LA rebellion does indicate that style in some sense still functions as a 'vessel for content, issues and ideas'. Caldwell, Televisuality, pp. 5, 30235

${ }^{22}$ The unaided human eye can, under the right circumstances, see objects as small as $0.1 \mathrm{~mm}$ long (roughly the equivalent of one-fifth the size of a grain of salt).

${ }^{23}$ A light (optical) microscope uses a system of lenses and the magnification is limited by the wavelength of visible light, thus only allowing for a useful magnification of approximately 500-2000x. In turn, an electron microscope uses an electron beam, which can produce a photographic magnification of 1000,000x.

${ }^{24}$ Franklin 'Global nature and the genetic imaginary', p. 189; Nikolas Rose, The Politics of Life Itself:

Biomedicine, Power, and Subjectivity in the Twenty-First Century (Princeton, NJ: Princeton University Press), 2007, pp. 5, 11-15.

${ }^{25}$ Rose, The Politics of Life Itself, pp. 11-15.

${ }^{26}$ Barbara Ley, Nathalie Jankowski and Paul R. Brewer, 'Investigating CSI: portrayals of DNA testing on a forensic crime show and their potential effects', Public Understanding of Science, 27 May 2010, p. 10.

${ }^{27}$ Nelkin and Lindee, The DNA Mystique, pp. 1-2.

${ }^{28}$ Ibid., pp. 149-68, 194

${ }^{29}$ Ibid., p. 194.

${ }^{30}$ Ley, Jankowski and Brewer, 'Investigating CSI', p. 11.

${ }^{31}$ Cartwright, Screening the Body, pp. 84-90.

${ }^{32}$ Ibid., p. 91

${ }^{33}$ Caldwell, Televisuality, pp. 6, 91-92

${ }^{34}$ See Nigel Thrift, 'The place of complexity', Theory, Culture and Society, vol. 16, no. 3 (1999), pp. 31-69;

John Urry, 'The complexity turn', Theory, Culture and Society, vol. 22, no. 5 (2005), pp. 1-14; Brian Wynne,

'Reflexing complexity: post-genomic knowledge and reductionist returns in public science', Theory, Culture and Society, vol. 22, no. 5 (2005), pp. 67-94.

${ }^{35}$ See Wynne, 'Reflexing complexity', p. 68; Evelyn Fox Keller, 'The century beyond the gene', Journal of Bioscience, vol. 30, no. 1 (2005), pp. 6, 9; Sarah Franklin, Dolly Mixtures: the Remaking of Genealogy (Durham, NC: Duke University Press, 2007), p. 33.

${ }^{36}$ See Rose, The Politics of Life Itself, p. 14; Paul Rabinow and Carlo Caduff, 'Life - after Canguilhem', Theory, Culture and Society, vol. 23, nos 2-3 (2006), pp. 329-30.

${ }^{37}$ Franklin, 'Global nature and the genetic imaginary', pp. 215-22; Rose, The Politics of Life Itself, pp. $15-27$.

${ }^{38}$ Wynne, 'Reflexing complexity', p. 67.

${ }^{39}$ Stacey, The Cinematic Life of the Gene, pp. 6-7.

${ }^{40}$ Ibid., p. 6.

${ }^{41}$ See Thrift, 'The place of complexity', pp. 32-33; Urry, 'The complexity turn', pp. 4-5.

${ }^{42}$ See, for example: Jane Feuer, 'Melodrama, Serial Film and Television Today', Screen, 25(1), (1984), pp. 416; Jeffrey Scone, 'What If: Charting Television's New Textual Boundaries' in Lynn Spigel and Jan Olsson (eds.), Television After TV: Essays on a Medium in Transition (Durham: Duke University Press, 2004), pp. 39112; Angela Ndalianis, 'Television and the Neo-Baroque' in Lucy Mazdon and Michael Hammond (eds.), The Contemporary Television Serial (Edinburgh: University of Edinburgh Press, 2005), pp. 83-101; Jason Mittell, 'Narrative complexity in contemporary American television', The Velvet Light Trap, no. 58 (2006), pp. 29-40; Henry Jenkins, Convergence Culture: Where Old and New Media Collide (New York, NY: New York University Press, 2006); Paul Booth, Time on TV: Temporal Displacement and Mashup Television (New York, NY: Peter Lang, 2012).

${ }^{43}$ Mittell, 'Narrative complexity in contemporary American television', pp. 29-40.

${ }^{44}$ Ibid., p. 32, and Jason Mittell, 'Lost in a great story: evaluation in narrative television (and television studies)', in Roberta Pearson (ed.), Reading LOST: Perspectives on a Hit Television Show (London: IB Tauris, 2009), pp. 119-38.

${ }^{45}$ See Elke Weissman, 'The victim's suffering translated: CSI: Crime Scene Investigation and the crime genre', Intensities: the Journal of Cult Media, no. 4 (2007),

$<$ http://intensitiescultmedia.files.wordpress.com/2012/12/weissmann-victims-suffering-translated.pdf $>$ accessed 17 December 2014; Derek Kompare, CSI (Malden: Wiley-Blackwell, 2010), p. 14.

${ }^{46}$ Robin Nelson, TV Drama in Transition: Forms, Values and Cultural Change (London: Macmillan, 1997).

${ }^{47}$ Gever, 'The spectacle of crime digitized', p. 449. 
This is a pre-copy edited version of an article accepted for publication in Screen (Volume 56, Number 1, Spring, 2015) following peer-review. The definitive publisher authenticated version is available from:

http://screen.oxfordjournals.org/content/56/1/64.abstract

${ }^{48}$ See Richard Neupert, The End: Narration and Closure in the Cinema (Detroit, IL: Wayne State University Press, 1995).

${ }^{49}$ James MacDowell, 'Does the Hollywood happy ending exist?', in Armelle Parey, Isabelle Robin and Dominque Sipière (eds), Happy Endings and Films (Paris: Michel Houdiard, 2010), p. 16.

${ }^{50}$ Ibid., pp. 17-18.

${ }^{51}$ Mittell, 'Narrative complexity in contemporary American television', p. 34

${ }^{52}$ See Edward N. Lorenz, 'Deterministic nonperiodic flow', Journal of the Atmospheric Sciences, vol. 20, no. 2 (1963), pp. 130-41.

${ }^{53}$ John Urry, 'The complexities of the global', Theory, Culture and Society, vol. 22, no. 5 (2005), p. 238.

${ }^{54}$ Elke Weissmann, The Forensic Sciences of CSI: How to Know about Crime (Saarbrücken: VDM Verlag Dr Müller, 2010), p. 160.

${ }^{55}$ See Thrift, 'The place of complexity', p. 34; Urry, 'The complexity turn', pp. 1-3.

${ }^{56}$ See Steven Cohan, TV Classics: CSI: Crime Scene Investigation (London: BFI Publishing, 2008), pp. 1-6; Kompare, CSI, p. 2; Weissmann, The Forensic Sciences of CSI, pp. 9-10. 